\title{
Subtercola boreus gen. nov., sp. nov. and Subtercola frigoramans sp. nov., two new psychrophilic actinobacteria isolated from boreal groundwater
}

\author{
M. K. Männistö, ${ }^{1}$ P. Schumann, ${ }^{2}$ F. A. Rainey, ${ }^{3}$ P. Kämpfer ${ }^{4}$ I. Tsitko, ${ }^{5}$ \\ M. A. Tiirola ${ }^{6}$ and M. S. Salkinoja-Salonen ${ }^{5}$
}

Author for correspondence: M. Männistö. Tel: +358 3365 2947. Fax: +358 33652869 e-mail: mannisto@cc.tut.fi

1 Institute of Water and Environmental Engineering, Tampere University of Technology, PO Box 541, 33101 Tampere, Finland

2 DSMZ-Deutsche Sammlung von Mikroorganismen und Zellkulturen $\mathrm{GmbH}$, Beutenbergstraße 11, 07745 Jena, Germany

3 Department of Biological Sciences, 508 Life Sciences Building, Louisiana State University, Baton Rouge, LA 70803, USA

4 Institut für Angewandte Mikrobiologie, JustusLiebig Universität, Senckenbergstraße 3, D-35390 Giessen, Germany

5 Department of Applied Chemistry and Microbiology, PO Box 56 (Biocentre), 00014 University of Helsinki, Finland

6 Department of Bio and Environmental Sciences, University of Jyväskylä, PO Box 35, Jyväskylä, Finland

\begin{abstract}
Psychrophilic actinobacterial isolates from permanently cold groundwater in Finland were characterized using a polyphasic approach. Growth on agar plates was observed at temperatures down to $-2{ }^{\circ} \mathrm{C}$, with an optimum at $15-17{ }^{\circ} \mathrm{C}$, but no growth was observed at $30^{\circ} \mathrm{C}$. The peptidoglycan type was $\mathrm{B2} \gamma$ and the characteristic diamino acid was diaminobutyric acid. The cell wall sugars of strain $\mathrm{K265}^{\mathrm{T}}$ were rhamnose, ribose, xylose and mannose and those of strain $\mathrm{K}^{300^{\top}}$ were glucose, rhamnose and xylose. The polar lipids included phosphatidylglycerol, diphosphatidylglycerol, one unknown phospholipid and two glycolipids. The main whole-cell fatty acids were 12-methyltetradecanoic acid, 14-methylpentadecanoic acid and 14-methylhexadecanoic acid. Large amounts of anteiso-1,1-dimethoxy-pentadecane and also iso-1,1-dimethoxyhexadecane were present as diagnostic markers. The predominant menaquinones were MK-9 and MK-10. The G+C content of the DNA of strains

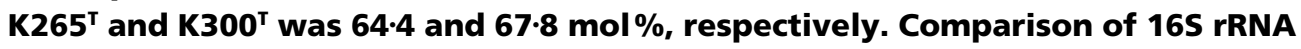
gene sequences revealed that strains $\mathrm{K}^{265^{\top}}$ and $\mathrm{K300}^{\top}$ represent a new lineage among the type-B-peptidoglycan actinomycetes. The closest relatives were Clavibacter michiganensis, Frigoribacterium faeni and Rathayibacter rathayi. On the basis of $16 S$ rDNA sequence, $G+C$ content and chemotaxonomical and physiological characteristics, $\mathrm{K}^{265^{\top}}$ and $\mathrm{K}^{2} 00^{\top}$ clearly represent a new genus. The genus Subtercola gen. nov. is described, together with two species, namely

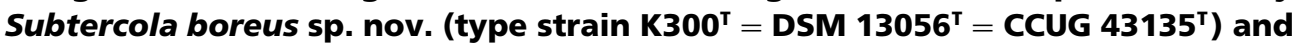

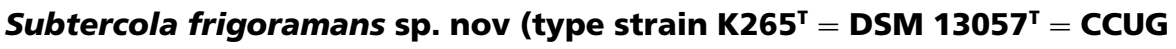
43136').
\end{abstract}

Keywords: Subtercola boreus gen. nov., sp. nov., Subtercola frigoramans sp. nov., psychrophilic actinobacteria, 1,1-dimethyl acetal

\section{INTRODUCTION}

The few psychrophilic or psychrotolerant actinobacterial species so far described belong to the genera Cryobacterium (Suzuki et al., 1997) and the recently described Frigoribacterium (Kämpfer et al., 2000). Analysis of whole-cell fatty acid composition and partial 16S rRNA gene sequencing indicated that several taxa of actinomycetes were present among 190

The EMBL accession numbers for the 16S rRNA gene sequences determined in this study are AF224723 (strain K265') and AF224722 (strain K300'). isolates from Finnish groundwater in which the temperature is stable at $7^{\circ} \mathrm{C}$ (Männistö et al., 1999; unpublished results). This paper is a polyphasic description of two novel actinomycetes, isolated from the groundwater, capable of growth on solid medium at temperatures down to $-2{ }^{\circ} \mathrm{C}$. The phylogenetic, chemotaxonomic and physiological data show that the two isolates represent a new genus within B-typepeptidoglycan-containing members of the family Microbacteriaceae. We propose a new genus, Subtercola gen. nov., and the species Subtercola boreus sp. nov. and Subtercola frigoramans sp. nov. for these strains. 


\section{METHODS}

Isolation. Strains $\mathrm{K} 265^{\mathrm{T}}$ and $\mathrm{K} 300^{\mathrm{T}}$ were isolated from the groundwater of a shallow aquifer located under a glacial gravel ridge in Southern Finland. The water was pumped from a subsurface depth of $18 \mathrm{~m}$. It was highly humic (with 4-13 mg dissolved organic carbon $\left.1^{-1}\right)$, rich in iron $(15 \mathrm{mg}$ $\left.1^{-1}\right)$ and had a stable temperature of $7 \pm 1^{\circ} \mathrm{C}$. The strains were isolated on PYGV agar plates (Staley, 1968) at $7 \pm 1{ }^{\circ} \mathrm{C}$. The cultures for characterization were grown on PYGV, TSA (BBL Microbiology Systems) or R2A (BBL Microbiology Systems) agar.

Morphology. The cultures were studied by phase-contrast microscopy $\left(8,24,48\right.$ and $72 \mathrm{~h}$ at $\left.20^{\circ} \mathrm{C}\right)$ using an Olympus $\mathrm{BH}-2$ light microscope. Gram-staining was performed using the Hucker method (Gerhardt et al., 1994). For the preparation of thin sections, the cultures were grown for $7 \mathrm{~d}$ on TSA agar at $8^{\circ} \mathrm{C}$. The cells were prefixed with $4 \%(\mathrm{v} / \mathrm{v})$ glutaraldehyde in $0 \cdot 1 \mathrm{M}$ sodium phosphate buffer $(\mathrm{pH} 7 \cdot 2)$ for $2 \mathrm{~h}$ at room temperature and washed three times in the same buffer. Thin sections were prepared and examined as described elsewhere (Väisänen et al., 1994).

Physiological characteristics. Growth on TSA plates at -2 , $0,2,4,8,10,15,20,25,28$ and $30^{\circ} \mathrm{C}$ was observed and recorded after $14 \mathrm{~d}$ and the growth rates on $\mathrm{PYGV}$ and trypticase soy broth were determined at 13,15, 17, 20 and $23^{\circ} \mathrm{C}$ by automated kinetic turbidometry (Bioscreen; LabSystems). The inoculum $(50 \mu \mathrm{l})$ was grown on PYGV plates for 3-4 d and suspended in PYGV broth to an optical density $(600 \mathrm{~nm})$ of $0 \cdot 3 ; 300 \mu \mathrm{l}$ PYGV or TSA was pipetted into each well. Growth, with medium shaking, was measured as turbidity using a wide-band filter $(450-580 \mathrm{~nm})$ and BIOLINK (Labsystems) software. Physiological tests were performed on microtitre plates as described elsewhere (Kämpfer et al., 1991) and read after $3 \mathrm{~d}$ at $20^{\circ} \mathrm{C}$.

Chemotaxonomic analyses. For whole-cell fatty acid analysis, the strains were grown on TSA at $4,10,15,20$ and $25^{\circ} \mathrm{C}$ for 3-12 d. Fatty acid methyl esters were prepared and analysed as described previously (Väisänen et al., 1994). Fatty acid methyl esters were identified using the MIDI aerobic library (TSBA, version 3.9; MIDI). 1,1-Dimethyl acetals were identified as described by Kämpfer et al. (2000). Peaks in the whole-cell methanolysate not identifed with the MIDI aerobic library version 3.9, were rerun using the BHIBLA anaerobic library and also analysed by GC-MS using the Wiley $138 \mathrm{~K}$ and NIST mass-spectral libraries. Methanolysates of Propionibacterium freudenreichii DSMZ $20271^{\mathrm{T}}$ and Propionibacterium jensenii DSMZ 20535 ${ }^{\mathrm{T}}$ were used as references for 1,1-dimethyl acetals.

Purified cell wall preparations were obtained as described by Schleifer \& Kandler (1972). Amino acids and peptides in cell wall hydrolysates were analysed by two-dimensional TLC on cellulose plates, using the solvent systems described by Schleifer \& Kandler (1972). The molar ratios of cell wall amino acids were determined by GC and GC-MS of $N$ heptafluorobutyryl amino acid isobutyl esters (MacKenzie, 1987). Cell wall sugars were determined by GC of alditol acetals as described by Groth et al. (1996).

Menaquinones were extracted as described by Collins et al. (1977) and analysed by HPLC (Groth et al., 1996). Polar lipids extracted by the method of Minnikin et al. (1979) were identified by two-dimensional TLC followed by spraying with specific reagents (Collins \& Jones, 1980).

Base composition of DNA. DNA was extracted after lysis with proteinase $\mathrm{K}$ and purified with phenol/chloroform and chloroform-isoamyl alcohol extractions, 2-propanol precipitation and caesium chloride gradient purification as described by Wilson (1994). Hydrolysis, dephosphorylation and HPLC measurement were performed as described by Johnson (1994). The HPLC column was a Purospher RP-18 endcapped reversed-phase column $(250 \mathrm{~mm} \times 4.0 \mathrm{~mm}$ i.d., $5.0 \mu \mathrm{m}$ particle size; Merck). The mobile phase was $20 \mathrm{mM}$ triethylamine phosphate $(\mathrm{pH} 5 \cdot 1)$ in $12 \%$ methanol. The

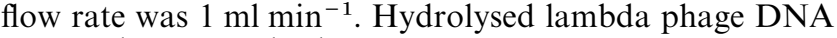
was used as a standard.

$16 S$ rRNA gene sequence determination and phylogenetic analyses. The extraction of genomic DNA, PCR amplification of the 16S rRNA gene and sequencing of the purified PCR products were carried out as described previously (Rainey et al., 1996). Sequence reaction products were purified by ethanol precipitation and electrophoresed with a model 310 Genetic Analyzer (Applied Biosystems). The 16S rRNA gene sequences obtained in this study were aligned against the previously determined actinobacterial sequences available from the public databases, using the ae 2 editor (Maidak et al., 1999). The programs of the PHYLIP package, including DNADIST and NEIGHBOR, were used for the phylogenetic analyses (Felsenstein, 1993). The method of Jukes \& Cantor (1969) was used to calculate evolutionary distances. The tree topology was re-analysed using 1000 bootstrapped data sets and the programs SEQBOOT, DNADIST and CONSENSE of the PHYLIP package (Felsenstein, 1993).

Nucleotide sequence accession numbers. The accession numbers and strain designations of the reference 16S rRNA gene sequences used in the phylogenetic analyses are as follows: Agrococcus jenensis DSM 9580 (X92492), Agromyces ramosus DSM 43045 ${ }^{\mathrm{T}}$ (X77447), Agromyces mediolanus DSM 20152 (X77449), Arthrobacter globiformis DSM 20124 (M23411), 'Brevibacterium helvolum' DSM 20419 (X77440), Clavibacter michiganense subsp. michiganense DSM 46364 ${ }^{\mathrm{T}}$ (X77435), 'Corynebacterium aquaticum' DSM $20146^{\mathrm{T}}$ (X77450), Cryobacterium psychrophilum IAM12024 (D45058), Curtobacterium citreum DSM 20528 ${ }^{\mathrm{T}}$ (X77436), Curtobacterium luteum DSM 20542 ${ }^{\mathrm{T}}$ (X77437), Frigoribacterium faeni DSM 46346 ${ }^{\mathrm{T}}$ (Y18807), Leucobacter komagatae IFO $15245^{\mathrm{T}}$ (D17751), Microbacterium aurum IFO $15204^{\mathrm{T}}$ (D21340), Microbacterium barkeri DSM 20145 (X77446), Microbacterium imperiale DSM 20530 (X77442), Microbacterium lacticum DSM 20427 ${ }^{\mathrm{T}}$ (X77441), Microbacterium liquefaciens DSM 20638 ${ }^{\mathrm{T}}$ (X77437), Rathayibacter rathayi DSM 7458 ${ }^{\mathrm{T}}$ (X77439), Rathayibacter toxicus JCM $9669^{\mathrm{T}}(\mathrm{D} 84127)$.

\section{RESULTS}

\section{Morphological and physiological characteristics}

Strains $\mathrm{K} 265^{\mathrm{T}}$ and $\mathrm{K} 300^{\mathrm{T}}$ formed yellow colonies within $3-4 \mathrm{~d}$ at $20^{\circ} \mathrm{C}$. K265 $5^{\mathrm{T}}$ formed large, mucoid, pale yellow colonies on PYGV or R2A agar; K300 ${ }^{\mathrm{T}}$ was less slimy. On TSA agar, the strains formed smooth, round, convex, non-slimy, yellow colonies. The microscopic investigations showed that the cells of strain $\mathrm{K} 300^{\mathrm{T}}$ were irregular, short, sometimes slightly curved rods $0 \cdot 2-0.3 \mu \mathrm{m}$ in width and $0.6-1.0 \mu \mathrm{m}$ in length. The cells of strain $\mathrm{K} 265^{\mathrm{T}}$ were irregular, pleomorphic rods $0.3-0.4 \mu \mathrm{m}$ in width and $0.9-1.5 \mu \mathrm{m}$ in length. Young cells of $\mathrm{K} 265^{\mathrm{T}}$ were frequently swollen at the pole or in the middle. The non-motile cells stained Gram-positive at the early stages of 


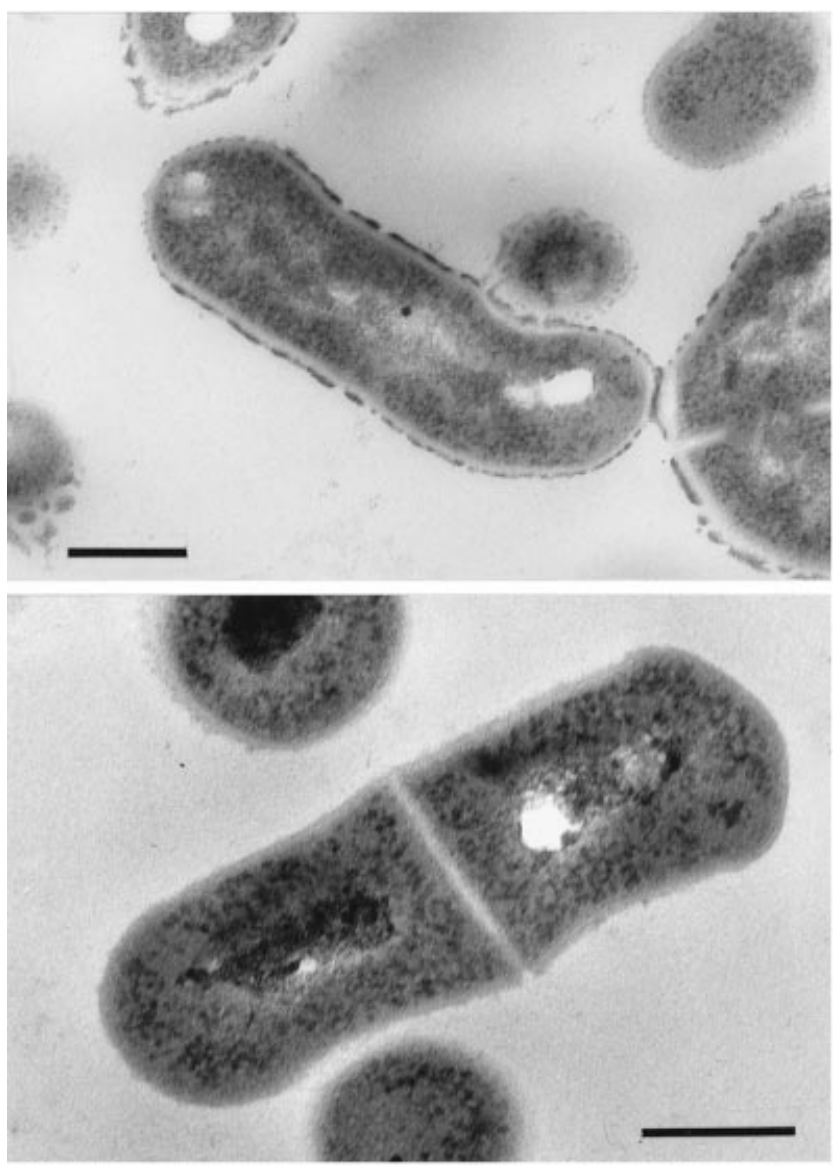

Fig. 1. Electron micrographs of thin sections of strains $K 300^{\top}$ (top) and $\mathrm{K}^{265^{\top}}$ (bottom) grown on tryptic soy agar plates for $7 \mathrm{~d}$ at $8^{\circ} \mathrm{C}$. Bar, $200 \mathrm{~nm}$.

growth $\left(24 \mathrm{~h}\right.$ at $\left.20^{\circ} \mathrm{C}\right)$. Both strains turned into short, coccoid rods in the late stages of growth $(>48 \mathrm{~h}$ at $20^{\circ} \mathrm{C}$ ). When grown in liquid medium, $\mathrm{v}$ - and $\mathrm{y}$-forms were frequently seen. Micrographs of thin sections of strains $\mathrm{K} 300^{\mathrm{T}}$ and $\mathrm{K} 265^{\mathrm{T}}$ are shown in Fig. 1. Cells of both strains had the typical morphology of Grampositive bacteria, i.e. a cell membrane surrounded by an amorphous layer. The cells exhibited a perpendicular type of division. Cells of strain $\mathrm{K} 300^{\mathrm{T}}$ had an irregular, electron-dense outer layer.

Growth was optimal at $15-17^{\circ} \mathrm{C}$. The growth rates of strain $\mathrm{K} 265^{\mathrm{T}}$ on PYGV medium were 0.017 and 0.018 $1 / \mathrm{h}$ at 15 and $17^{\circ} \mathrm{C}$, respectively; the growth rate of strain $\mathrm{K} 300^{\mathrm{T}}$ was $0.0231 / \mathrm{h}$ at both temperatures. Visible colonies formed within $14 \mathrm{~d}$ at $+2{ }^{\circ} \mathrm{C}$ and, in the case of strain $\mathrm{K} 265^{\mathrm{T}}$, even at $-2{ }^{\circ} \mathrm{C}$. The colony morphology was similar at $-2{ }^{\circ} \mathrm{C}$ and $20^{\circ} \mathrm{C}$.

The metabolic properties of strains $\mathrm{K} 265^{\mathrm{T}}$ and $\mathrm{K} 300^{\mathrm{T}}$ are shown in Table 1. A wide variety of sugars were assimilated but none of the 11 amino acids tested was used. The strains differed from each other in their ability to assimilate substrates such as rhamnose, ribose, acetate, propionate, cis-aconitate and citrate.
Table 1. Physiological characteristics of the strains $\mathrm{K} 265^{\top}$ and $\mathrm{K} 300^{\top}$

Both strains assimilated L-arabinose, D-cellobiose, D-fructose, D-galactose, gluconate, D-glucose, D-mannose, D-maltose, sucrose, D-trehalose, D-xylose, adonitol, D-mannitol, fumarate, DL-3-hydroxybutyrate and 4-hydroxybenzoate. Neither strain utilized $N$-acetyl-D-galactosamine, $N$-acetyl-Dglucosamine, $\alpha$-D-melibiose, maltitol, D-sorbitol, putrescine, trans-aconitate, adipate, 4-aminobutyrate, azelate, glutarate, itaconate, DL-lactate, L-malate, mesaconate, oxoglutarate, pyruvate, suberate, L-alanine, $\beta$-alanine, L-aspartate, L-histidine, L-leucine, L-ornithine, L-phenylalanine, L-proline, L-serine, L-tryptophan or phenylacetate. Both strains hydrolysed aesculin, $\mathrm{pNP}-\alpha$-D-glucopyranoside and $\mathrm{pNP}-\beta$-Dglucopyranoside. Neither strain hydrolysed pNP-phenylphosphonate, $\mathrm{pNP}-\beta$-D-galactopyranoside, $\mathrm{pNP}$-phosphorylcholine, 2-deoxythymidine-5'-pNP-phosphate, L-alanine-paranitroanilide, L-glutamate- $\gamma$-3-carboxy-pNA or L-proline-paranitroanilide. Abbreviation: pNP, para-nitrophenyl.

\begin{tabular}{|lcc|}
\hline Characteristic & \multicolumn{2}{c|}{ Reaction of: } \\
\cline { 2 - 3 } & K265 $^{\mathbf{T}}$ & $\mathbf{K 3 0 0}^{\mathbf{T}}$ \\
\hline Assimilation of: & & \\
$p$-Arbutin & + & - \\
L-Rhamnose & - & + \\
D-Ribose & - & + \\
Salicin & + & - \\
i-Inositol & - & + \\
Citrate & - & + \\
3-Hydroxybenzoate & - & + \\
Acetate & - & + \\
Propionate & - & + \\
cis-Aconitate & - & + \\
Hydrolysis of: & & + \\
pNP- $\beta$-D-Glucuronide & - & - \\
pNP- $\beta$-D-Xylopyranoside & + & + \\
Bis-pNP-phosphate & - & \\
\hline
\end{tabular}

\section{Chemotaxonomic characteristics}

The polar lipids in $\mathrm{K} 265^{\mathrm{T}}$ and $\mathrm{K} 300^{\mathrm{T}}$ consisted of phosphatidylglycerol, diphosphatidylglycerol, one unidentified phospholipid and two unidentified glycolipids.

The diamino acid in the peptidoglycan of strains $\mathrm{K} 265^{\mathrm{T}}$ and $\mathrm{K} 300^{\mathrm{T}}$ was diaminobutyric acid (DAB). The molar ratio of alanine:glycine:glutamic acid: DAB was, for strain $\mathrm{K} 265^{\mathrm{T}}, 0 \cdot 6: 1 \cdot 2: 0 \cdot 1: 2 \cdot 0$; for strain $\mathrm{K} 300^{\mathrm{T}}$, the ratio was $0 \cdot 6: 1 \cdot 1: 0 \cdot 1: 2 \cdot 0$. The amino acid ratio (except that of glutamic acid) is consistent with peptidoglycan type B2 $\gamma$ (Schleifer \& Kandler, 1972). This peptidoglycan type was confirmed by characteristic two-dimensional thin-layer chromatographic peptide patterns of partial hydrolysates of cell walls (data not shown). The low content of glutamic acid in the hydrolysates was due to nearly complete substitution of D-glutamic acid at position 2 of the 
Table 2. Composition of whole-cell methanolysates of strains $K 265^{\top}$ and $K 300^{\top}$ grown at different temperatures

Strains were grown on trypticase soy agar for 3-14 d.

\begin{tabular}{|c|c|c|c|c|c|c|c|c|c|c|c|c|c|c|c|}
\hline \multirow[t]{3}{*}{ Strain } & \multirow{3}{*}{$\begin{array}{c}\text { Growth } \\
\text { temp. }\left({ }^{\circ} \mathrm{C}\right)\end{array}$} & \multicolumn{6}{|c|}{ Saturated/monounsaturated fatty acids $(\%)^{*}$} & \multicolumn{5}{|c|}{ 1,1-Dimethyl acetals $(\%)^{*}$} & \multirow{2}{*}{\multicolumn{3}{|c|}{$\begin{array}{c}\text { Unknown compounds } \\
(\%) \dagger \text { ECL }\end{array}$}} \\
\hline & & i- & i- & i- & a- & a- & a- & a- & a- & 1 & 1 & & & & \\
\hline & & $14: 0$ & $15: 0$ & $16: 0$ & $15: 0$ & $17: 0$ & $15: 1$ & $15: 0$ & $17: 0$ & $15: 0$ & $16: 0$ & $16: 0$ & $13 \cdot 56$ & $14 \cdot 26$ & $14 \cdot 57$ \\
\hline \multirow[t]{5}{*}{$\mathrm{K} 265^{\mathrm{T}}$} & 4 & $3 \cdot 4$ & - & $10 \cdot 6$ & $45 \cdot 0$ & $2 \cdot 1$ & $10 \cdot 4$ & $14 \cdot 4$ & - & - & $9 \cdot 1$ & - & $3 \cdot 0$ & - & $1 \cdot 5$ \\
\hline & 10 & $6 \cdot 1$ & - & $8 \cdot 4$ & $46 \cdot 0$ & $3 \cdot 5$ & $2 \cdot 2$ & $16 \cdot 7$ & $1 \cdot 2$ & - & $10 \cdot 9$ & - & $2 \cdot 5$ & - & 1.5 \\
\hline & 15 & $10 \cdot 9$ & - & $9 \cdot 7$ & $44 \cdot 1$ & $3 \cdot 9$ & $\operatorname{tr}$ & $13 \cdot 9$ & $1 \cdot 4$ & - & $12 \cdot 3$ & - & - & - & $1 \cdot 8$ \\
\hline & 20 & $7 \cdot 5$ & - & $9 \cdot 8$ & $44 \cdot 8$ & $3 \cdot 9$ & - & $13 \cdot 5$ & $1 \cdot 8$ & - & $13 \cdot 2$ & - & $1 \cdot 6$ & - & $2 \cdot 3$ \\
\hline & 25 & $6 \cdot 7$ & $\operatorname{tr}$ & $10 \cdot 2$ & $46 \cdot 1$ & $6 \cdot 8$ & - & $10 \cdot 3$ & $2 \cdot 9$ & - & $13 \cdot 3$ & - & - & - & $2 \cdot 1$ \\
\hline \multirow[t]{5}{*}{$\mathrm{K} 300^{\mathrm{T}}$} & 4 & - & $6 \cdot 9$ & $3 \cdot 2$ & $38 \cdot 2$ & $1 \cdot 0$ & $6 \cdot 4$ & $19 \cdot 6$ & $0 \cdot 6$ & $3 \cdot 4$ & $6 \cdot 3$ & - & $4 \cdot 7$ & - & $9 \cdot 1$ \\
\hline & 10 & $3 \cdot 3$ & $1 \cdot 1$ & $5 \cdot 1$ & $49 \cdot 5$ & $1 \cdot 2$ & $\operatorname{tr}$ & $19 \cdot 4$ & $0 \cdot 8$ & $\mathrm{tr}$ & $10 \cdot 5$ & $1 \cdot 3$ & $3 \cdot 0$ & $\mathrm{tr}$ & $1 \cdot 5$ \\
\hline & 15 & $1 \cdot 5$ & $0 \cdot 9$ & $4 \cdot 4$ & $53 \cdot 8$ & $2 \cdot 1$ & - & $20 \cdot 6$ & $0 \cdot 9$ & $\operatorname{tr}$ & $7 \cdot 9$ & $\operatorname{tr}$ & $3 \cdot 1$ & $1 \cdot 4$ & $1 \cdot 3$ \\
\hline & 20 & - & $1 \cdot 7$ & $4 \cdot 2$ & $54 \cdot 5$ & $3 \cdot 0$ & - & $18 \cdot 2$ & $1 \cdot 5$ & 0.9 & $7 \cdot 8$ & $\operatorname{tr}$ & $3 \cdot 5$ & $1 \cdot 4$ & $1 \cdot 1$ \\
\hline & 25 & $\operatorname{tr}$ & $4 \cdot 3$ & $4 \cdot 2$ & $51 \cdot 6$ & $3 \cdot 5$ & $\operatorname{tr}$ & $11 \cdot 0$ & $4 \cdot 0$ & $1 \cdot 7$ & 11.9 & $\operatorname{tr}$ & $2 \cdot 0$ & - & $2 \cdot 6$ \\
\hline
\end{tabular}

* Per cent of total peak area of the ion chromatogram; tr, traces $(<1 \%)$; a, anteiso-branched acid; i, iso-branched acid.

$\dagger$ Unknown compounds not identified by the MIDI fatty acid methyl ester database (version 3.9) or by the mass-spectral libraries Wiley $138 \mathrm{~K}$ or NIST (\% of total peak area of the total-ion chromatogram); ECL, equivalent chain length.

peptide subunit by threo-3-hydroxyglutamic acid, as revealed by two-dimensional TLC and GC-MS.

The cell wall sugars of strain $\mathrm{K} 265^{\mathrm{T}}$ included rhamnose, ribose and small amounts of xylose and mannose. Glucose, rhamnose and small amounts of xylose were present in the cell wall of strain $\mathrm{K} 300^{\mathrm{T}}$.

The major isoprenoid quinones of $\mathrm{K} 265^{\mathrm{T}}$ were MK-9 (36\%), MK-10 (32\%), MK-12 (18\%), MK-13 (4\%), MK-11 (4\%) and MK-8 (4\%) and those of K300 were MK-10 (58\%), MK-9 (30\%), MK-11 (8\%) and MK-8 (2\%). The G $+\mathrm{C}$ content of the genomic DNA of strain $\mathrm{K} 265^{\mathrm{T}}$ and strain $\mathrm{K} 300^{\mathrm{T}}$ was 64.4 and $67 \cdot 8$ mol \%, respectively.

\section{Cellular fatty acid compositions}

The results of the gas chromatographic data for wholecell methanolysates of strains $\mathrm{K} 265^{\mathrm{T}}$ and $\mathrm{K} 300^{\mathrm{T}}$ are shown in Table 2. It shows that in both strains all identified significant fatty acids were of the branchedchain type, mainly 12-methyl tetradecanoic acid (a-15:0) and 14-methyl pentadecanoic acid (i-16:0). In addition the strain K265 contained 12-methyl tridecanoic acid (i-14:0) and both strains contained unsaturated 12-methyl tetradecanoic acid (a-15:1) when grown at temperatures of $\leqslant 15^{\circ} \mathrm{C}$. In addition to fatty acids, several major peaks in the whole-cell methanolysates (Fig. 2a) were identified as branched-chain C15, C16 and C17 1,1-dimethyl acetals. The BHIBLA anaerobic library and mass-spectral analysis, using $P$. freudenreichii DSMZ 20271 ${ }^{\mathrm{T}}$ and $P$. jensenii DSMZ $20535^{\mathrm{T}}$ as standards for 1,1-dimethyl acetals, proved that the major peak of $\mathrm{K} 265^{\mathrm{T}}$ and $\mathrm{K} 300^{\mathrm{T}}$ (with an
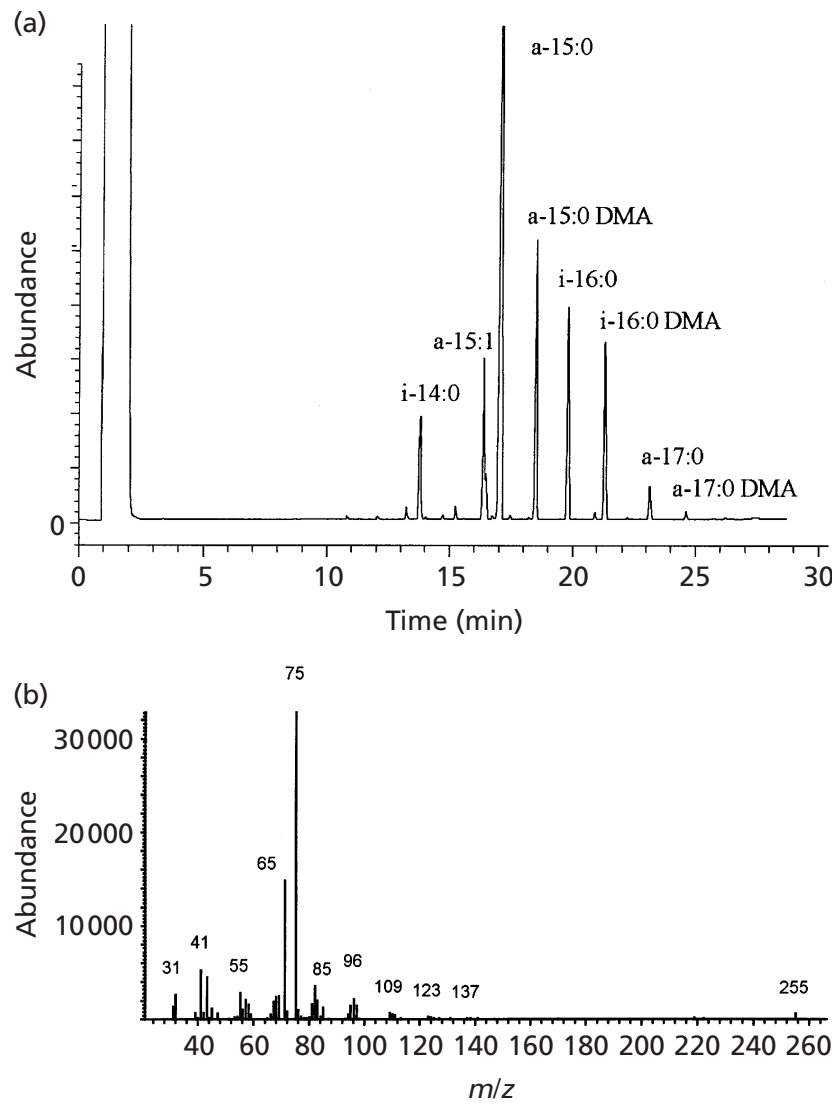

Fig. 2. (a) Total-ion gas chromatogram of a whole-cell methanolysate of strain $\mathrm{K}^{2} 65^{\top}$ grown on tryptic soy agar plates at $6{ }^{\circ} \mathrm{C}$; $\mathrm{i}$, iso-branched; a, anteiso-branched; DMA, 1,1-dimethyl acetal. (b) Mass fragmentogram of 1,1-dimethoxy-hexadecane (i-16:0 DMA). 


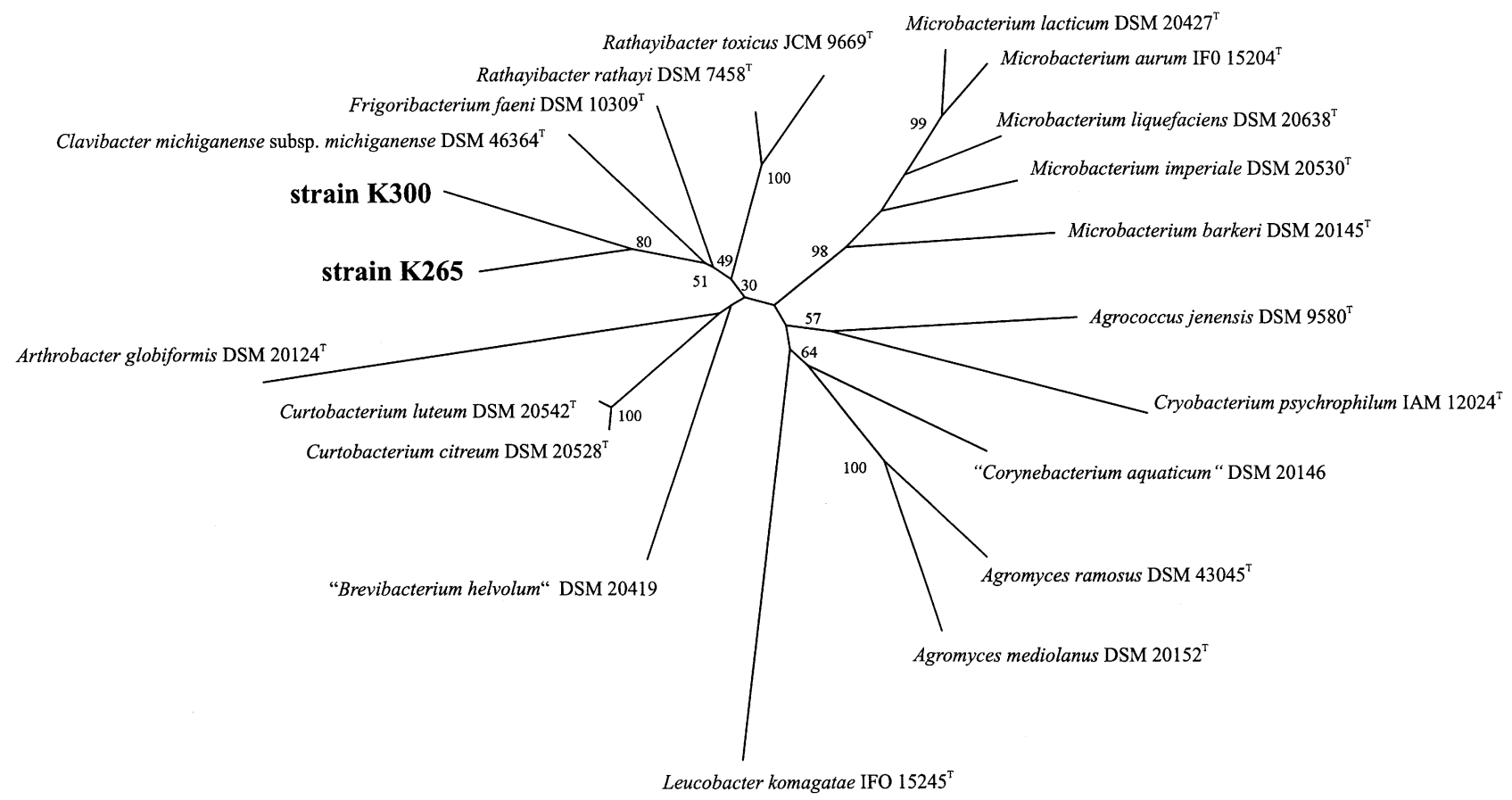

$10 \%$

Fig. 3. Phylogenetic tree based on $16 \mathrm{~S}$ rRNA gene sequence comparison, demonstrating the positions of strains $\mathrm{K} 265^{\top}$ and $\mathrm{K} 300^{\top}$. Bar, 10 nucleotide substitutions per 100 nucleotides.

equivalent chain length of 15.197) was 1,1-dimethoxyanteiso-pentadecane (Fig. 2a). Methanolysates of the strains $\mathrm{K} 265^{\mathrm{T}}$ and $\mathrm{K} 300^{\mathrm{T}}$ contained several peaks with the mass fragment at $\mathrm{m} / \mathrm{z} 75$ diagnostic for branchedchain 1,1-dimethyl acetals (Fig. 2b). Such peaks in the $\mathrm{K} 265^{\mathrm{T}}$ methanolysates were identified, on the basis of their mass fragments, as 1,1-dimethoxy-anteiso-pentadecane (a-15:0 DMA), 1,1-dimethoxy-iso-hexadecane (i-16:0 DMA) and 1,1-dimethoxy-anteiso-heptadecane (a-17:0 DMA) (Table 2). In addition, small amounts of 1,1-dimethoxy-iso-pentadecane (i-15:0 DMA) and a straight-chain 1,1-dimethoxy-hexadecane (16:0 DMA) were identified in strain $\mathrm{K} 300^{\mathrm{T}}$. Three peaks in the methanolysates of strains $\mathrm{K} 265^{\mathrm{T}}$ and $\mathrm{K} 300^{\mathrm{T}}$ remained unidentified.

\section{Effect of temperature on cellular fatty acid compositions}

The effect of cultivation temperature on the whole-cell fatty acid composition of the new isolates was unusual. Strain $\mathrm{K} 300^{\mathrm{T}}$ reduced its anteiso-15:0 content and both strains reduced their anteiso-17:0 content as the growth temperature was reduced (Table 2). When grown at $4{ }^{\circ} \mathrm{C}, \mathrm{K} 265^{\mathrm{T}}$ and $\mathrm{K} 300^{\mathrm{T}}$ contained $6-10 \%$ anteiso-15:1. Moreover, cultivation temperature influenced the 1,1-dimethyl acetal composition of strains $\mathrm{K} 265^{\mathrm{T}}$ and $\mathrm{K} 300^{\mathrm{T}}$. As the growth temperature was lowered from 25 to $4{ }^{\circ} \mathrm{C}$, the contribution of the anteiso-15:0 DMA, the main DMA in the whole-cell methanolysates, increased in both strains from 10-11 to $14-20 \%$, whereas the contributions of anteiso- $17: 0$ DMA and iso-16:0 DMA fell accordingly. Thus, it appears that a low growth temperature favoured the synthesis of DMAs with shorter carbon chain lengths, a shift from iso-branched DMAs to anteiso-branched congeners, or both.

\section{S rRNA gene sequence comparison}

Almost complete 16S rRNA gene sequences 1467 (strain $\mathrm{K} 300^{\mathrm{T}}$ ) and 1472 (strain $\mathrm{K} 265^{\mathrm{T}}$ ) nucleotides in length were determined. Phylogenetic analyses based on a data set comprising 1330 unambiguous nucleotides between positions 38 and 1478 but excluding positions $97-193$ [due to the absence of this region in the reference sequence of L. komagatae (D17751)] (Escherichia coli positions; Brosius et al., 1978) showed that the new isolates cluster together as distinct lineages within the radiation of the actinomycete genera with group-B-peptidoglycan that comprises the family Microbacteriaceae (Stackebrandt et al., 1997) (Fig. 3). Strains K $300^{\mathrm{T}}$ and $\mathrm{K} 265^{\mathrm{T}}$ share $97.0 \% 16 \mathrm{~S}$ rRNA gene sequence similarity (data not shown). The new isolates show the highest levels of 16S rRNA gene sequence similarity with species of the genera Frigoribacterium (95.5-96.7\%), Clavibacter (95.1-97.1\%) and Rathayibacter (94.3-96.7\%) (data not shown). Species of the genera Clavibacter, Frigoribacterium and Rathayibacter share $96 \cdot 1-97 \cdot 0 \%$ 16S rRNA gene 
sequence similarity (data not shown). The bootstrap analyses indicate no significance in the branching pattern of the lineage comprising the new isolates and any previously described generic lineage of this family (Fig. 3).

\section{DISCUSSION}

The characteristics that differentiate the strains $\mathrm{K} 265^{\mathrm{T}}$ and $\mathrm{K} 300^{\mathrm{T}}$ from the genera Clavibacter, Rathayibacter, Cryobacterium and Frigoribacterium are shown in Table 3. Clavibacter and Frigoribacterium species contain MK-9 as the predominant menaquinone, whereas Rathayibacter and Cryobacterium species contain MK-10 (Sasaki et al., 1998; Kämpfer et al., 2000; Suzuki et al., 1997). Strains K $265^{\mathrm{T}}$ and K $300^{\mathrm{T}}$ contained both MK-9 and MK-10 in almost equal proportions. In addition, K265 ${ }^{\mathrm{T}}$ contained MK-12 and MK-13, which are absent in strain $\mathrm{K} 300^{\mathrm{T}}$ and in species of Clavibacter, Frigoribacterium and Rathayibacter. The principal phospholipids of $\mathrm{K} 265^{\mathrm{T}}$ and $\mathrm{K} 300^{\mathrm{T}}$ were similar to those of Clavibacter (Collins \& Jones, 1980), Rathayibacter (Zgurskaya et al., 1993), Frigoribacterium (Kämpfer et al., 2000) and Cryobacterium (Suzuki et al., 1997).

The whole-cell methanolysates of strains $\mathrm{K} 265^{\mathrm{T}}$ and $\mathrm{K} 300^{\mathrm{T}}$ contained predominantly iso- and anteisobranched fatty acids and 1,1-dimethyl acetals. The whole-cell methanolysates of strains $\mathrm{K} 265^{\mathrm{T}}$ and $\mathrm{K} 300^{\mathrm{T}}$ were quite similar to that of $F$. faeni, only differing in their content of several different iso- and anteisobranched 1,1-dimethyl acetals (Table 3). However, the peptidoglycan type of Frigoribacterium was $\mathrm{B} 2 \beta$, whereas that of strains $\mathrm{K} 265^{\mathrm{T}}$ and $\mathrm{K} 300^{\mathrm{T}}$ was $\mathrm{B} 2 \gamma$.

The amino acid ratio in the peptidoglycan of strains $\mathrm{K} 265^{\mathrm{T}}$ and $\mathrm{K} 300^{\mathrm{T}}$ differed from that of other DABcontaining genera (Table 3) in the low levels of glutamic acid. In strains $\mathrm{K} 265^{\mathrm{T}}$ and $\mathrm{K} 300^{\mathrm{T}}$, nearly all of the glutamic acid residues at position 2 of the peptide subunit were replaced by hydroxy-glutamic acid. More or less complete hydroxylation of Dglutamic acid has been observed also in other representatives of the peptidoglycan-B-type cross-linkage, e.g. in Microbacterium species (Schleifer et al., 1967).

The optimal growth temperatures of strains $\mathrm{K} 265^{\mathrm{T}}$ and $\mathrm{K} 300^{\mathrm{T}}$ were around 10 degrees lower, down to $-2{ }^{\circ} \mathrm{C}$ for $\mathrm{K} 265^{\mathrm{T}}$, than those in the genera Clavibacter (Davis et al., 1984) and Rathayibacter (Zgurskaya et al., 1993). The new genus Frigoribacterium (Kämpfer et al., 2000), recently described and isolated from a Finnish farming environment, showed a similar growth-temperature range, whereas Cryobacterium (Suzuki et al., 1997) did not grow above $18^{\circ} \mathrm{C}$. Psychrophilic actinobacteria proposed as species of Arthrobacter have been reported recently (Vasil'eva et al., 1998; Loveland-Curtze et al., 1999). 'Arthrobacter crygenae' strain Z-0064 had an optimal growth temperature of $6{ }^{\circ} \mathrm{C}$ and did not grow above $15^{\circ} \mathrm{C}$ (Vasil'eva et al., 1998), whereas 'Arthrobacter psychrolactophilus' strains had growth ranges of $0-30{ }^{\circ} \mathrm{C}$ (Loveland-Curtze et al., 1999).

Decreases in temperature influenced both the fatty acid and dimethyl acetal compositions of the strains

Table 3. Diagnostic and differentiating characteristics of the genera Clavibacter, Rathayibacter, Frigoribacterium, Cryobacterium and strains $\mathrm{K}^{265^{\top}}$ and $\mathrm{K} 300^{\top}$

+, Positive reaction; -, negative reaction; (+), varies among different strains; A, anteiso-branched; I, iso-branched; S, straightchain saturated.

\begin{tabular}{|c|c|c|c|c|c|c|}
\hline Characteristic & Clavibacter* $^{*}$ & Rathayibacter $\dagger$ & Frigoribacterium & Cryobacterium $\S$ & $\mathrm{K}^{265^{\mathrm{T}}}$ & $\mathrm{K}^{300^{\mathrm{T}}}$ \\
\hline Peptidoglycan type & $\mathrm{B} 2 \gamma$ & $\mathrm{B} 2 \gamma$ & $\mathrm{B} 2 \beta$ & $\mathrm{B} 2 \gamma$ & $\mathrm{B} 2 \gamma$ & $\mathrm{B} 2 \gamma$ \\
\hline Cell wall diamino acid & DAB & DAB & D-Lysine & DAB & DAB & DAB \\
\hline Major menaquinone(s) & MK-9 & MK-10 & MK-9 & MK10 & MK-9, MK-10 & MK-9, MK-10 \\
\hline $\mathrm{G}+\mathrm{C}$ content $(\mathrm{mol} \%)$ & $67-78$ & $67-78$ & 71 & $66 \cdot 5$ & 64 & 68 \\
\hline \multicolumn{7}{|l|}{ Main cell wall sugars: } \\
\hline Glucose & + & + & & - & - & + \\
\hline Galactose & + & $(+)$ & & - & - & - \\
\hline Mannose & + & + & & - & + & - \\
\hline Ribose & - & - & & - & + & - \\
\hline Rhamnose & + & + & & + & + & + \\
\hline Fucose & - & - & & + & - & - \\
\hline Xylose & - & $(+)$ & & - & + & + \\
\hline Major fatty acid types & A, I, S & A, I, S & A, I, S & A, I, S & A, I & A, I \\
\hline Major 1,1-dimethyl acetals & - & - & $a-15: 0$ & - & $\begin{array}{c}a-15: 0, \\
\text { i-16:0, a-17:0 }\end{array}$ & $\begin{array}{c}a-15: 0, \text { i- } 16: 0, \\
\text { i- } 15: 0, a-17: 0,16: 0\end{array}$ \\
\hline Growth temp. range $\left({ }^{\circ} \mathrm{C}\right)$ & & & $0-28$ & $<18$ & $-2-28$ & $2-28$ \\
\hline Optimal growth temp. $\left({ }^{\circ} \mathrm{C}\right)$ & $20-29$ & $24-28$ & & $9-12$ & $15-17$ & $15-17$ \\
\hline Isolation source & Plant material & Plant material & Farm air & Antarctic soil & Boreal groundwater & Boreal groundwater \\
\hline
\end{tabular}

* Data from Groth et al. (1996).

$\dagger$ Data from Zgurskaya et al. (1993).

† Data from Kämpfer et al. (2000).

$\S$ Data from Suzuki et al. (1997). 
$\mathrm{K} 265^{\mathrm{T}}$ and $\mathrm{K} 300^{\mathrm{T}}$. Strains $\mathrm{K} 265^{\mathrm{T}}$ and $\mathrm{K} 300^{\mathrm{T}}$ increased their content of anteiso 15:1 fatty acid at cold temperatures, as reported for C.psychrophilum (Suzuki et al., 1997) and F. faeni (Kämpfer et al., 2000).

1,1-Dimethyl acetals are formed by the methanolysis of alk-1'-enyl glyceryl ethers (plasmalogens) (Jantzen $\&$ Hofstad, 1981). Plasmalogens are known to occur as significant components of animal cell membranes and in many obligately anaerobic bacteria such as Fusobacterium spp. (Jantzen \& Hofstad, 1981), clostridia (Johnston \& Goldfine, 1994), Megasphaera elsdenii (Kaufman et al., 1990) and Eubacterium lentum (Verhulst et al., 1987). 1,1-Dimethyl acetals were detected in the anaerobic actinobacterial species Propionibacterium freudenreichii and $P$. jensenii (Kämpfer et al., 2000).1,1-Dimethyl acetals were recently detected also in the aerobic psychrophilic $F$. faeni belonging to the same actinobacterial family (Microbacteriaceae) as strains $\mathrm{K} 265^{\mathrm{T}}$ and $\mathrm{K} 300^{\mathrm{T}}$ (Kämpfer et al., 2000).

The biological function of plasmalogens is not known but Kaufman et al. (1990) showed that membranes of M. elsdenii (with high plasmalogen content) were more ordered than membranes devoid of plasmalogens. This may indicate that the changes in the plasmalogenderived 1,1-dimethyl acetal composition may reflect a role in membrane fluidity.

On the basis of the presence of several unusual 1,1dimethyl acetals, other distinctive chemotaxonomic features and the 16S rRNA gene sequence, we propose that strains $\mathrm{K} 265^{\mathrm{T}}$ and $\mathrm{K} 300^{\mathrm{T}}$ should be placed in a new genus, namely Subtercola gen. nov. The $16 \mathrm{~S}$ rRNA gene sequence comparisons clearly indicate that the strains $\mathrm{K} 265^{\mathrm{T}}$ and $\mathrm{K} 300^{\mathrm{T}}$ represent new taxa within the family Microbacteriaceae. It should be noted that the degree of $16 \mathrm{~S}$ rRNA gene sequence divergence between these two strains $(3 \%)$ is more than that found between strain $\mathrm{K} 265^{\mathrm{T}}$ and Clavibacter michiganense subsp. michiganense (which share 97.1\% similarity) and is the same as that found between $F$. faeni and C. michiganense subsp. michiganense (3\%). The influence of this sequence divergence is also seen in the results of phylogenetic analyses in which the bootstrap values indicate that there is no significance in the branching point joining the $\mathrm{K} 265^{\mathrm{T}}$ and $\mathrm{K} 300^{\mathrm{T}}$ lineages. Based on the results of $16 \mathrm{~S}$ rRNA gene sequence analyses it could be proposed that the two strains represent different genera. However, there is little chemotaxonomic and phenotypic data to support this and we therefore propose, at this time, that these two strains should be included in a single genus as two novel species, for which we propose the names $S u b$ tercola boreus gen. nov., sp. nov. and Subtercola frigoramans gen. nov., sp. nov.

\section{Description of Subtercola gen. nov.}

Subtercola (sub.ter'co.la. L. prep. subter below, underneath; L. masc. suffix n. -cola inhabitant; M.L. masc.n. subtercola the one who lives underneath).
Aerobic, Gram-positive, irregular rods. Cells occur singly or in v-forms. Endospores are not produced. The colonies are pale to bright yellow depending on the culture medium. The colonies are circular, convex and smooth. Grows optimally at $15-17^{\circ} \mathrm{C}$. Growth is observed in the temperature range $2-28^{\circ} \mathrm{C}$. The cell wall diamino acid is DAB. The main cell wall amino acids are alanine, glycine, threo-3-hydroxy-glutamic acid and DAB. The peptidoglycan type is $\mathrm{B} 2 \gamma$. The polar lipids are phosphatidylglycerol, diphosphatidylglycerol, one unknown phospholipid and two glycolipids. The main cellular fatty acids are 12-methyltetradecanoic acid (a-15:0), 14-methylpentadecanoic acid (i-16:0) and 14-methylhexadecanoic acid (a17:0). The whole-cell methanolysates of Subtercola sp. contain 1,1-dimethoxy-anteiso-pentadecane (a-15:0 DMA) and 1,1-dimethoxy-iso-hexadecane (i-16:0 DMA) as major components in amounts comparable to those of fatty acids. The major isoprenoic quinones are MK-9 and MK-10. The G + C content of the DNA is $64-68 \mathrm{~mol} \%$. No mycolic acids are present. The type species is Subtercola boreus.

\section{Description of Subtercola boreus sp. nov.}

Subtercola boreus (bo.re'us. L. adj. boreus Northern, referring to the boreal groundwater aquifer in Finland, from which the organism was isolated).

Cells are short, irregular rods $0 \cdot 2-0 \cdot 3 \mu \mathrm{m}$ in width and $0.6-1.0 \mu \mathrm{m}$ in length. Colonies are yellow, circular, convex and smooth. Growth occurs at $2-28{ }^{\circ} \mathrm{C}$. The major cellular fatty acids are 12-methyltetradecanoic acid (a-15:0), 14-methylpentadecanoic acid (i-16:0), 14-methylhexadecanoic (a-17:0) acid and 13-methyltetradecanoic acid (i-15:0). 1,1-Dimethoxy-iso-pentadecane (i-15:0 DMA), 1,1-dimethoxy-anteiso-heptadecane (a-17:0 DMA) and 1,1-dimethoxy-hexadecane (16:0 DMA) are found in whole-cell methanolysates. The cell wall contains glucose, rhamnose and xylose. Other chemotaxonomic characteristics are as described for the genus. Good carbon sources include L-arabinose, D-cellobiose, D-fructose, D-galactose, gluconate, D-glucose, D-mannose, D-maltose, Lrhamnose, D-ribose, sucrose, D-trehalose, D-xylose, adonitol, i-inositol, D-mannitol, acetate, propionate, cis-aconitate, citrate, fumarate, DL-3-hydroxybutyrate, 3-hydroxybenzoate and 4-hydroxybenzoate. Amino acids are mostly not utilized. The $\mathrm{G}+\mathrm{C}$ content of the DNA is $68 \mathrm{~mol} \%$. Isolated from groundwater. The type strain is $\mathrm{K}^{300^{\mathrm{T}}}\left(=\mathrm{DSM} 13056^{\mathrm{T}}=\mathrm{CCUG}\right.$ $\left.43135^{\mathrm{T}}\right)$.

\section{Description of Subtercola frigoramans sp. nov.}

Subtercola frigoramans (fri.gor.a'mans. L. neut. n. frigus the cold; L. gen. neut. n. frigoris of the cold; L. part. pres. amans loving; M.L. part. pres. frigoramans loving the cold).

Cells are pleomorphic, irregular rods $0 \cdot 3-0 \cdot 4 \mu \mathrm{m}$ in width and $0.9-1.5 \mu \mathrm{m}$ in length. In liquid culture the cells may be arranged in v- or y-forms. Colonies are 
pale yellow to bright yellow depending on the culture medium. Large, mucoid colonies are formed on glucose-containing medium. Growth occurs at $-2{ }^{\circ} \mathrm{C}$ to $28{ }^{\circ} \mathrm{C}$. The major cellular fatty acids are 12 methyltetradecanoic acid (a-15:0), 14-methylpentadecanoic acid (i-16:0), 14-methylhexadecanoic acid (i-17:0) and 12-methyltridecanoic acid (i-14:0). 1,1Dimethoxy-anteiso-heptadecane (a-17:0 DMA) is found in whole-cell methanolysates. The cell wall contains rhamnose, ribose, xylose and mannose. The main isoprenoid quinones are MK-10 and MK-9. Other chemotaxonomical characteristics are the same as described for the genus. Good carbon sources include L-arabinose, $p$-arbutin, D-cellobiose, D-fructose, D-galactose, gluconate, D-glucose, D-mannose, D-maltose, sucrose, salicin, D-trehalose, D-xylose, adonitol and D-mannitol. Acetate, propionate, aconitate and most amino acids are not assimilated. Fumarate, but not citrate, is assimilated. The $\mathrm{G}+\mathrm{C}$ content of the DNA is $64 \mathrm{~mol} \%$. Isolated from groundwater. The type strain is $\mathrm{K} 265^{\mathrm{T}}$ (= DSM $13057^{\mathrm{T}}=$ CCUG $43136^{\mathrm{T}}$ ).

\section{ACKNOWLEDGEMENTS}

This work was supported by the Academy of Finland (grant nos 34519 and 46569). We thank Maria Anderson for advice on whole-cell fatty acid analysis, Raimo Mikkola for expertise with the GC-MS analysis and Arja Strandell for thin-section preparation. We thank the Division of Electron Microscopy at the Institute of Biotechnology at Helsinki University for the lease of equipment. We are grateful to H. G. Trüper for the Latin construction of the genus and species names. We thank Jani Salminen for the water-quality monitoring data for the aquifer.

\section{REFERENCES}

Brosius, J., Palmer, M. L., Kennedy, J. P. \& Noller, H. F. (1978). Complete nucleotide sequence of the ribosomal RNA gene from Escherichia coli, Proc Natl Acad Sci USA 75, 4801-4805.

Collins, M. D. \& Jones, D. (1980). Lipids in the classification and identification of coryneform bacteria containing peptidoglycans based on 2,4-diaminobutyric acid, J Appl Bacteriol 48, 459-470.

Collins, M. D., Pirouz, T., Goodfellow, M. \& Minnikin, D. E. (1977). Distribution of menaquinones in actinomycetes and corynebacteria, J Gen Microbiol 100, 221-230.

Davis, M. J., Gillespie, A. G., Jr, Vidaver, A. K. \& Harris, R. W. (1984). Clavibacter: a new genus containing some phytopathogenic coryneform bacteria, including Clavibacter xyli subsp. xyli sp. nov., subsp. nov. and Clavibacter xyli subsp. Cynodontis subsp. nov., pathogens that cause ratoon stunting disease of sugarcane and bermudagrass stunting disease, Int $J$ Syst Bacteriol 34, 107-117.

Felsenstein, J. (1993). PHYLIP (Phylogenetic Inference Package) version 3.5.1 Department of Genetics, University of Washington, Seattle, WA, USA.

Gerhardt, P., Murray, R. G. E., Wood, W. A. \& Krieg, N. R. (1994). Methods for General and Molecular Bacteriology. Washington, DC: American Society for Microbiology.

Groth, I., Schumann, P., Weiss, N., Martin, K. \& Rainey, F. A. (1996). Agrococcus jenensis gen. nov., sp. nov., a new genus of actinomycetes with diaminobutyric acid in the cell wall, Int $J$ Syst Bacteriol 46, 234-239.

Jantzen, E. \& Hofstad, T. (1981). Fatty acids of Fusobacterium species: taxonomic implications, J Gen Microbiol 123, 163-172.

Johnson, J. L. (1994). Similarity analysis of DNAs. In Methods for General and Molecular Bacteriology, pp. 655-682. Edited by P. R. Gerhardt, G. E. Murray, W. A. Wood \& N. R. Krieg. Washington, DC: American Society for Microbiology.

Johnston, N. C. \& Goldfine, H. (1994). Isolation and characterization of new phosphatidylglycerol acetals of plasmalogens. A family of ether lipids in clostridia, Eur J Biochem 223, 957-963.

Jukes, T. H. \& Cantor, C. R. (1969). Evolution of protein molecules. In Mammalian Protein Metabolism, vol. 3, pp. 21-132. Edited by H. N. Munro. New York: Academic Press.

Kämpfer, P., Steiof, M. \& Dott, W. (1991). Microbiological characterization of a fuel-oil contaminated site including numerical identification of heterotrophic water and soil bacteria, Microb Ecol 21, 227-251.

Kämpfer, P., Rainey, F. A., Andersson, M. A., Nurmiaho-Lassila, E.-L., Ulrych, U., Busse, H.-J., Weiss, N., Mikkola, R. \& SalkinojaSalonen, M. (2000). Frigoribacterium faeni gen. nov., sp. nov., a novel psychrophilic genus of the family Microbacteriaceae, Int J Syst Bacteriol 50, 355-363.

Kaufman, A. E., Goldfine, H., Narayan, O. \& Gruner, S. M. (1990). Physical studies on the membranes and lipids of plasmalogendeficient Megasphaera elsdenii, Chem Phys Lipids 55, 41-48.

Loveland-Curtze, J., Sheridan, P. P., Gutshall, K. R. \& Brenchley, J. E. (1999). Biochemical and phylogenetic analyses of psychrophilic isolates belonging to the Arthrobacter subgroup and description of Arthrobacter psychrolactophilus, sp. nov, Arch Microbiol 171, 355-363.

MacKenzie, S. L. (1987). Gas chromatographic analysis of amino acids as the $N$-heptafluorobutyryl isobutyl esters, $J$ Assoc Off Anal Chem 70, 151-160.

Maidak, B. L., Cole, J. R., Parker, C. T., Jr \& 11 other authors (1999). A new version of the RDP (Ribosomal Database Project). Nucleic Acids Res 27, 171-173.

Männistö, M. K., Tiirola, M. A., Salkinoja-Salonen, M. S., Kulomaa, M. \& Puhakka, J. A. (1999). Diversity of chlorophenoldegrading bacteria isolated from contaminated boreal groundwater, Arch Microbiol 171, 189-197.

Minnikin, D. E., Collins, M. D. \& Goodfellow, M. (1979). Fatty acid and polar lipid composition in the classification of Cellulomonas, Oerskovia and related taxa, J Appl Bacteriol 47, 87-95.

Rainey, F. A., Ward-Rainey, N., Kroppenstedt, R. M. \& Stackebrandt, E. (1996). The genus Nocardiopsis represents a phylogenetically coherent taxon and a distinct actinomycete lineage: proposal of Nocardiopsiaceae fam. nov, Int J Syst Bacteriol 46, 28-96.

Sasaki, J., Chijimatsu, M. \& Suzuki, K. (1998). Taxonomic significance of 2,4-diaminobutyric acid isomers in the cell wall peptidoglycan of actinomycetes and reclassification of Clavibacter toxicus as Rathayibacter toxicus comb. nov, Int $J$ Syst Bacteriol 48, 403-410.

Schleifer, K. H. \& Kandler, O. (1972). Peptidoglycan types of bacterial cell walls and their taxonomic implications, Bacteriol Rev 36, 407-477.

Schleifer, K. H., Plapp, R. \& Kandler, O. (1967). Identification of threo-3-hydroxyglutamic acid in the cell wall of Microbacterium lacticum, Biochem Biophys Res Commun 28, 566-570.

Stackebrandt, E., Rainey, F. A. \& Ward-Rainey, N. L. (1997). 
Proposal for a new hierarchic classification system, Actinobacteria classis nov, Int J Syst Bacteriol 47, 479-491.

Staley, J. T. (1968). Prosthecomicrobium and Ancalomicrobium: new prosthecate freshwater bacteria, J Bacteriol 95, 1921-1942.

Suzuki, K.-I., Sasaki, J., Uramoto, M., Nakase, T. \& Komagata, K. (1997). Cryobacterium psychrophilum gen. nov., sp. nov., nov. rev., comb. nov., an obligately psychrophilic actinomycete to accommodate 'Curtobacterium psychrophilum' Inoue and Komagata 1976, Int J Syst Bacteriol 47, 474-478.

Väisänen, O. M., Nurmiaho-Lassila, E. L., Marmo, S. A. \& Salkinoja-Salonen, M. S. (1994). Structure and composition of biological slimes of paper and board machines, Appl Environ Microbiol 60, 641-653.

Vasil'eva, L. V., Savel'eva, N. D., Omel'chenko, M. V., Lysenko, A. M., Pusheva, M. A., Trotsenko, Y. A. \& Zavarzin, G. A. (1998).
Arthrobacter crygenae sp. nov. and Acidovorax psychrofacilis sp. nov., psychrophilic hydrogen bacteria from tundra soil, Microbiology 64, 195-200.

Verhulst, A., Van Hespen, H., Symons, F. \& Eyssen, H. (1987). Systematic analysis of the long-chain components of Eubacterium lentum, J Gen Microbiol 133, 275-282.

Wilson, K. (1994). Preparation of genomic DNA from bacteria. In Current Protocols in Molecular Biology, pp. 2.4.1-2.4.5. Edited by F. M. Ausubel, R. Brent, R. E. Kingston, D. D. Moore, J. G. Seidman, J. A. Smith \& K. Struhl. New York: Wiley.

Zgurskaya, H. I., Evtushenko, L. I., Akimov, V. N. \& Kalakoutskii, L. V. (1993). Rathayibacter gen. nov., including the species Rathayibacter rathayi comb. nov., Rathayibacter tritici comb. nov., Rathayibacter iranicus comb. nov., and six strains from annual grasses, Int J Syst Bacteriol 43, 143-149. 